\title{
THE BLOOD PICTURE IN EXOPHTHALMIC GOITRE AND ITS CHANGES RESULTING FROM IODINE AND OPERATION. A STUDY BY MEANS OF THE SUPRAVITAL TECHNIQUE
}

\author{
By SAUL HERTZ ${ }^{1}$ AND J. LERMAN \\ (From the Thyroid Clinic and Metabolism Laboratory of the Massachusetts General Hospital \\ Boston)
}

(Received for publication April 29, 1932)

The purpose of this report is to record a series of cases of exophthalmic goitre studied intensively by the supravital technique of blood examination. This method was chosen as being particularly suited to the problem since it affords a clear differentiation of the large lymphocyte, monocyte and transitional polymorphonuclear cells, a distinction which is not always possible in the ordinary type of fixed smear.

\section{HISTORICAL}

While Ciuffini (1) described relative lymphocytosis in exophthalmic goitre in 1904, this aspect of the disease did not attract universal attention until the publications of L. Caro (2) (3). In the year 1907 the latter author described a case of fatal exophthalmic goitre with such atypical findings in the blood that he thought he was dealing with an associated pseudoleukemia. Later (1908) he collected a series of cases showing similar blood pictures. Caro was furthermore able to produce the changes in the blood of normal individuals by the oral administration of thyroid gland. He showed that patients with non-toxic varieties of goitre did not have any alteration in their blood picture. The studies of Kocher (4) in 1908 received the attention of the entire medical profession. He described a triad of blood findings in Basedow's disease which he thought could be used in the early diagnosis of the malady. This triad consisted of leukopenia, relative hypopolynucleosis and relative lymphocytosis. It has come to bear his name as the "Kocher blood picture." Crotti (5) was able to confirm the observations of Kocher and stated that the blood findings were helpful in diagnosing the disease and in estimating its severity.

Crotti (5) observed cases during the postoperative period before the introduction of iodine in the preoperative treatment. We quote him directly as follows: "The same day of the operation the lymphocytes diminish materially while the polynuclears increase; on the following days, however, the blood formula returns to its previous pathological state, and only then improves gradually in direct proportion with the disease and usually becomes normal in the cured cases."

DeQuervain (6) stated that the above changes were not limited to exophthalmic goitre, for they occurred in other types of thyroid dyscrasia. Müller (7), Bauer (8) and Lampe (9) were of the same opinion.

Probably the most extensive study of the subject was that of W. A. Plummer (10) in 1919. He examined the blood of 578 cases of hyperthyroidism and recorded an average leukocyte count of 6,793 cells per cu. $\mathrm{mm}$. The relative

\footnotetext{
${ }^{1}$ Dalton Scholar, Massachusetts General Hospital.
} 
lymphocytosis and hypopolynucleosis, although appreciable in his figures, were not as definite as those recorded by Kocher and Crotti. He found no relationship between the blood changes and mortality in his series, and concluded that the blood picture was of little aid in diagnosis or prognosis.

Menkin (11) in 1928 studied 100 case records of hyperthyroidism, and followed the blood changes in a small series of patients. His conclusions were that relative lymphocytosis was present in hyperthyroidism, but that it was more frequent and more marked in cases with definite exophthalmos. Examination of his protocols reveals that several of his cases of "hyperthyroidism with exophthalmos" had elevated monocyte percentages as well as relative lymphocytosis, a fact which he failed to note. He also presented data to show that after operative treatment of the disease there was a reversion toward a normal blood status. However, no account was taken in his study of the effect of preoperative medication per se on the blood picture.

Most recently, Jackson (12) concluded, from a study of the blood of 600 cases of thyroid disease of various forms, that there was no basis for the Kocher triad, that iodides had no effect on the blood formula, and that there was no parallelism in the height of basal metabolic rate, the severity of the disease and the differential blood picture.

\section{METHOD}

The method of blood examination used in this study has been described in detail by Sabin (13). It consists, in its main features, of the following steps: thin smears of non-toxic stains, neutral red and janus green, are made on clean, polished slides. Blood is received on a coverslip and allowed to spread on the thin film of stain. The coverslip is then rimmed with vaseline to prevent evaporation. The preparation is examined at body temperature in a warm box with oil immersion objective.

The appearance of the cells with this technique is such that cytoplasmic structure is more clearly made out than in fixed smear. The polymorphonuclear cells are the most conspicuous since their finely granular cytoplasm is in constant amoeboid motion. Lymphocytes are characterized by their lack of granulation, their high mitochondrial content and the paucity or complete absence of components staining with neutral red. The monocyte is motile, more so than the sluggish lymphocyte, and contains a few mitochondria. It is mainly identified by a group of granules which selectively take the neutral red stain and are arranged, for the most part, in the form of a rosette in the crescent of the large indented nucleus. Nuclear contour and consistency are readily appreciated in the supravital technique despite the fact that nuclear material does not take up the stains used. The chromatin network, fine in the monocyte and coarse in the lymphocyte, is a distinguishing feature.

\section{BLOOD PICTURE IN EXOPHTHALMIC GOITRE}

MATERIAL

Since our preliminary study indicated that exophthalmic goitre was more apt to show an altered blood picture than other types of goitre, we 
decided to study only those cases in which a definite diagnosis of exophthalmic goitre had been made by the Thyroid Clinic. Only patients who had not received iodine previous to hospitalization were included. Care was exercised to allow for the factors known to affect the blood formula. Counts were done at approximately the same hour each time for individual patients, usually between 2:30 and 4:00 P.M.

We were unable to demonstrate any changes of importance in the blood picture on rest alone during the four or five day period when levels of metabolism and blood counts were being obtained. The results for thirty consecutive cases are given in Table 1 .

TABLE 1

Initial levels of basal metabolic rate and blood findings in 30 patients with exophthalmic goitre

\begin{tabular}{|c|c|c|c|c|c|c|c|}
\hline $\begin{array}{l}\text { Patient } \\
\text { number }\end{array}$ & $\begin{array}{c}\text { Leuko- } \\
\text { cytes }\end{array}$ & $\begin{array}{l}\text { Basal } \\
\text { metabolic } \\
\text { rate }\end{array}$ & $\begin{array}{l}\text { Neutro- } \\
\text { philes* }\end{array}$ & $\begin{array}{l}\text { Lympho- } \\
\text { cytes }\end{array}$ & Monocytes & $\begin{array}{c}\text { Eosino- } \\
\text { philes }\end{array}$ & Basophiles \\
\hline $\begin{array}{r}1 \\
2 \\
3 \\
4 \\
5 \\
6 \\
7 \\
8 \\
9 \\
10 \\
11 \\
12 \\
13 \\
14 \\
15 \\
16 \\
17 \\
18 \\
19 \\
20 \\
21 \\
22 \\
23 \\
24 \\
25 \\
26 \\
27 \\
28 \\
29 \\
30\end{array}$ & $\begin{array}{r}5,000 \\
6,000 \\
4,300 \\
9,200 \\
4,850 \\
5,900 \\
5,000 \\
6,500 \\
6,800 \\
7,800 \\
6,800 \\
6,850 \\
5,100 \\
5,900 \\
5,450 \\
7,150 \\
4,200 \\
6,250 \\
5,000 \\
6,250 \\
4,700 \\
6,900 \\
5,700 \\
8,200 \\
6,500 \\
13,000 \\
10,400 \\
6,800 \\
5,750 \\
6,600\end{array}$ & $\begin{array}{c}\text { per cent } \\
60 \\
48 \\
68 \\
74 \\
50 \\
44 \\
52 \\
58 \\
47 \\
61 \\
56 \\
50 \\
56 \\
38 \\
36 \\
51 \\
52 \\
39 \\
30 \\
38 \\
30 \\
40 \\
24 \\
25 \\
42 \\
42 \\
40 \\
3\end{array}$ & $\begin{array}{c}\text { per cent } \\
55 \\
60 \\
65 \\
67 \\
50 \\
61 \\
64 \\
60 \\
65 \\
58 \\
54 \\
40 \\
66 \\
46 \\
54 \\
64 \\
45 \\
54 \\
52 \\
56 \\
58 \\
53 \\
63 \\
57 \\
62 \\
55 \\
6\end{array}$ & $\begin{array}{c}\text { per cent } \\
25 \\
20 \\
15 \\
15 \\
20 \\
24 \\
18 \\
15 \\
19 \\
29 \\
28 \\
38 \\
18 \\
37 \\
30 \\
14 \\
34 \\
25 \\
24 \\
30 \\
21 \\
20 \\
26 \\
2\end{array}$ & $\begin{array}{c}\text { per cent } \\
14 \\
11 \\
17 \\
18 \\
23 \\
10 \\
12 \\
20 \\
15 \\
13 \\
15 \\
18 \\
14 \\
13 \\
12 \\
19 \\
15 \\
16 \\
17 \\
12 \\
13 \\
15 \\
14 \\
10 \\
5 \\
15 \\
12 \\
15 \\
8 \\
12\end{array}$ & $\begin{array}{c}\text { per cent } \\
4 \\
5 \\
2 \\
0 \\
4 \\
4 \\
5 \\
3 \\
1 \\
0 \\
2 \\
2 \\
1 \\
4 \\
3 \\
3 \\
4 \\
5 \\
4 \\
1 \\
7 \\
2 \\
3 \\
6 \\
8 \\
4 \\
1 \\
3 \\
4 \\
5\end{array}$ & $\begin{array}{c}\text { per cent } \\
2 \\
4 \\
1 \\
0 \\
2 \\
1 \\
1 \\
2 \\
0 \\
0 \\
1 \\
2 \\
1 \\
0 \\
1 \\
0 \\
2 \\
0 \\
3 \\
1 \\
1 \\
0 \\
0 \\
1 \\
4 \\
3 \\
1 \\
0 \\
2 \\
1\end{array}$ \\
\hline $\begin{array}{l}\text { Average } \\
\text { Standard devi- } \\
\text { ation of av- } \\
\text { erage }\end{array}$ & $\begin{array}{r}6,495 \\
331\end{array}$ & $\begin{array}{r}45.1 \\
2.24\end{array}$ & $\begin{array}{r}56.9 \\
1.20\end{array}$ & $\begin{array}{r}24.5 \\
1.25\end{array}$ & $\begin{array}{l}14.1 \\
0.65\end{array}$ & 3.3 & $\begin{array}{l}1.2 \\
0.21\end{array}$ \\
\hline
\end{tabular}

* Includes stab forms of leukocytes. 
Most of the cases were of moderate severity as judged by the levels of metabolism. Twenty-three of the thirty cases fell into a group in which the basal metabolic rate varied from plus 30 to plus 59 . There were three cases in which the metabolic rates were higher, and four in which they were lower.

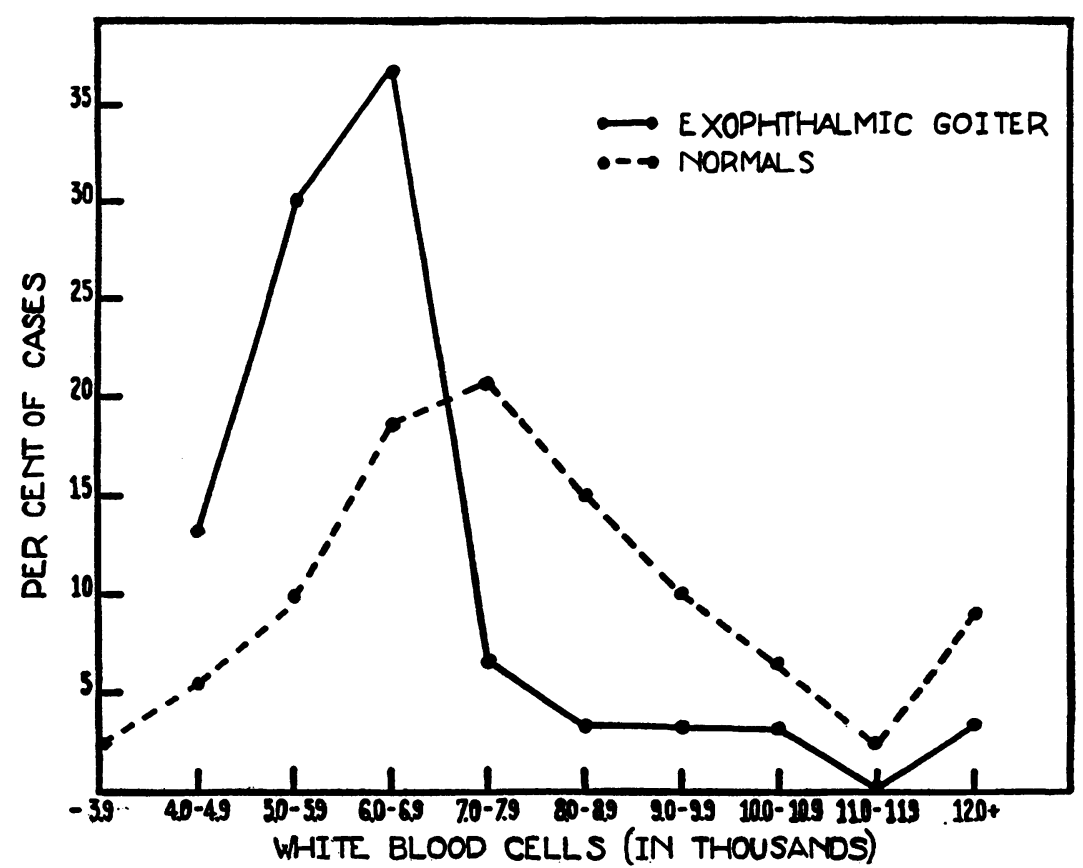

Fig. 1. Comparison of Average Leukocyte Counts in 30 Cases of ExOPHTHALMIC GoITRE aND 310 Normals

\section{Total white blood cells}

Figure 1 represents the percentage distribution of the white blood cell counts of 30 exophthalmic goitre patients and of 310 normal people collected by Lerman (14). The curves demonstrate that in exophthalmic goitre there is a skewness toward the leukopenic side of the blood picture. Of the goitre patients 80 per cent had counts below 7,000 cells, whereas only 36 per cent of normals had counts below this level. This points to the existence of a definite leukopenia in the disease, a fact which is not so obvious from the average leukocyte count of the series. The latter is $6,495 \pm 331$ cells. Compared to the normal average leukocyte count of $7,850 \pm 132$ cells as obtained by Lerman (14), the difference is $1,335 \pm 357$ or 3.8 times its standard deviation. It is, therefore, highly significant statistically. In this connection it is important to note that all the counts in our study were done in the afternoon and therefore represent the peak in the diurnal variation in total white blood cell 
counts (15). Morning counts in several instances were recorded as low as 2,400 to 3,100 in patients who had afternoon counts of 5,000 to 6,000 cells. This fact gives additional significance to the recorded difference.

\section{Differential blood picture}

Tables 2, 3, and 4 represent the distribution of the polymorphonuclear neutrophiles, lymphocytes and monocytes respectively. We have been unable to find any large series of normal differential counts made by the supravital technique. Consequently we cannot make a final comparison of the above distributions with the normal. The results given by Sabin

TABLE 2

The distribution of the neutrophilic leukocyte percentages of 30 patients with exophthalmic goitre

\begin{tabular}{|c|c|c|}
\hline $\begin{array}{l}\text { Neutrophiles } \\
\text { per cent }\end{array}$ & Number & Per cent \\
\hline$-45 \ldots$ & .. 2 & 6.6 \\
\hline $45-48$ & 2 & 6.6 \\
\hline $49-52$. & 3 & 10.0 \\
\hline $53-56$. & 9 & 30.0 \\
\hline $57-60$. & 6 & 20.0 \\
\hline $61-64$. & .6 & 20.0 \\
\hline $65-68 \ldots$ &. .2 & 6.6 \\
\hline
\end{tabular}

TABLE 3

The distribution of total lymphocyte percentages of 30 patients with exophthalmic goitre

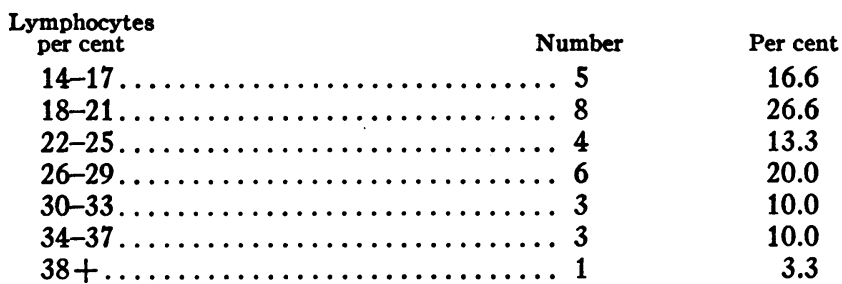

TABLE 4

The distribution of monocyte percentages of 30 patients with exophthalmic goitre

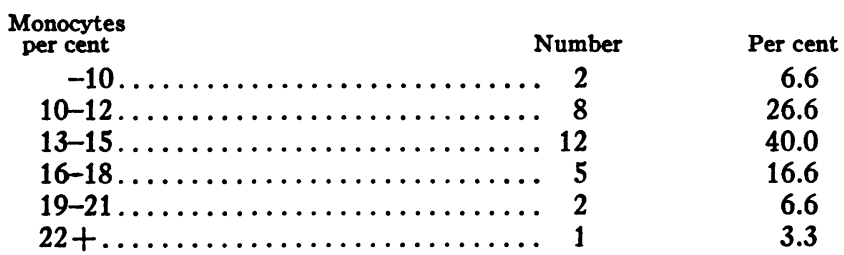

(15), based on 175 counts on six normal people, may be used tentatively as the normal level for the supravital method. In Table 5 these results are compared with the averages obtained in 30 patients with exophthalmic goitre. We cannot compare the absolute number of cells in the same way because Sabin's data do not contain the averages of the absolute numbers. However, normal averages may be obtained by multiplying 
Sabin's percentages by the normal total leukocyte count given above. These normals are of limited value because their standard deviations cannot be calculated.

\section{Polymorphonuclear neutrophiles}

The group distribution given in Table 2 does not show any distinct tendency to hypopolynucleosis in our series if the comparison is made with results based on the fixed smear method. However, compared to the results of Sabin (15), such a tendency is definite as revealed by the average figures given in Table 5 . The difference between the normal

TABLE 5

Comparison of the average percentages of the differential count in exophthalmic goitre and in normal people (Sabin)

\begin{tabular}{l|c|c|c|c|c}
\hline \hline & Neutrophiles & Lymphocytes & Monocytes & Eosinophiles & Basophiles \\
\cline { 2 - 5 } & per cent & per cent & per cent & per cent & per cent \\
$\begin{array}{l}\text { Exophthalmic goi- } \\
\text { tre }\end{array}$ & $56.9 \pm 1.20$ & $24.5 \pm 1.25$ & $14.1 \pm 0.65$ & $3.3 \pm 0.35$ & $1.2 \pm 0.21$ \\
Normal & $68.9 \pm 2.18$ & $19.7 \pm 1.20$ & $5.7 \pm 0.49$ & $4.4 \pm 1.15$ & $1.2 \pm 0.21$ \\
\hline $\begin{array}{c}\text { Difference between } \\
\text { exoph thal mic } \\
\text { goitre and nor- } \\
\text { mal averages }\end{array}$ & $12.0 \pm 2.49$ & $4.8 \pm 1.73$ & $8.4 \pm 0.81$ & $1.1 \pm 1.20$ & 0.0 \\
\hline
\end{tabular}

and exophthalmic goitre neutrophile counts is $12.0 \pm 2.49$ per cent, a value of high statistical significance. Moreover, since the diurnal variation in total white blood cell count is mainly attributable to the fluctuation of the neutrophiles, the above percentage of neutrophiles in exophthalmic goitre, obtained in the afternoon, represents the peak of the curve. Consequently hypopolynucleosis is actually greater throughout the day than our results indicate. The absolute numbers of neutrophiles in exophthalmic goitre is reduced to a greater extent than the percentage because of the simultaneous reduction in total leukocyte count. Thus the average neutrophile count for the exophthalmic goitre cases is 3,696 cells as compared with the normal of 5,409 cells.

\section{Lymphocytes}

The distribution of lymphocyte percentages is given in Table 3 . The average percentage is $24.5 \pm 1.25$, which is greater than the normal by $4.8 \pm 1.73$ per cent. The difference, though not large, indicates a significant tendency to relative lymphocytosis in exophthalmic goitre. About 68 per cent of the patients showed lymphocyte percentages above the normal average of 19.7 , and 23.3 per cent showed percentages of 30 or more. The absolute number of lymphocytes is about the same in the exophthalmic goitre group as in the normal. 


\section{Monocytes}

Table 4 shows the distribution of the monocytes in exophthalmic goitre. Obviously, almost all the patients had high monocyte counts. For example, only one patient had a count below Sabin's average normal of 5.7 per cent, whereas 26.5 per cent of the patients had counts over 15 . This would indicate that relative monocytosis, to the extent of 2 to 3 times the normal value, is a definite and characteristic finding in the blood picture of exophthalmic goitre. The degree of monocytosis is expressed by the difference of $8.4 \pm 0.81$ per cent between the normal and exophthalmic goitre values. This difference, being 10.4 times its standard deviation, is highly significant. The absolute number of monocytes in exophthalmic goitre is not increased as much as the percentage, the value being 916 cells as compared to the normal of 447 cells. The difference is large and significant.

\section{Eosinophiles and basophiles}

While an occasional case may show a high percentage of eosinophiles, such a finding is, however, not common. The average per cent of eosinophiles is lower than normal, but not significantly so. The absolute number is relatively lower than the percentage, namely, 214 cells against the normal of 345 cells. Although the difference seems large, it is probably not significant because the standard deviation of the normal eosinophile average is large.

There is no variation from the normal in the case of basophiles, either in per cent or in absolute number.

It is important to determine what relationship the white blood cell count and its differential picture have to the severity of the disease as measured by the basal metabolic rate, and to one another. There is no correlation whatever between the white blood cell count and the level of metabolism. The average count at different levels of metabolism varies a good deal, but in no consistent way.

There is a slight correlation between the percentage of polymorphonuclear cells and the metabolism, as indicated in Figure 2. The former tends to increase as the metabolism rises. For example, of the 12 cases with metabolic rates of 50 and over, 7 showed polymorphonuclear counts of 60 per cent or more; whereas only one of the 10 cases with metabolic rates under 40 showed this same percentage of polymorphonuclear cells. Mathematically this relationship, as expressed by the coefficient of correlation, is $+0.324 \pm 0.115$.

The lymphocytes, on the other hand, tend to vary inversely as the level of metabolism. This is also demonstrated graphically in Figure 2, which shows that the average lymphocyte percentage falls from 27.7 to 21.0 with the rise in level of metabolism. Expressing this fact in a different way, 4 of the 12 cases with metabolic rates of 50 and over had 
15 per cent or less of lymphocytes whereas none of the remaining cases had this percentage of lymphocytes. The coefficient of correlation in this case is $-0.39 \pm 0.109$.

Figure 2 also shows the tendency of the monocytes to increase with the height of the basal metabolic rate. For example, 9 of the 18 cases with metabolic rates under 50 showed a monocyte count of 12 per cent or less, whereas only one of the remaining 12 cases showed this percentage of monocytes. The coefficient of correlation is $+0.403 \pm 0.108-a$ value of probable significance.

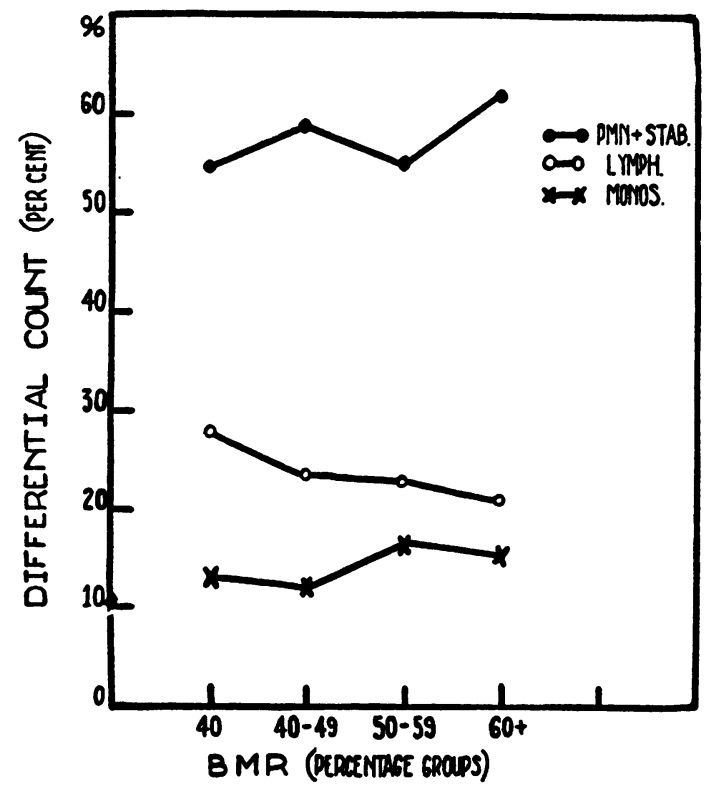

Fig. 2. The Average Percentage of Neutrophiles, Lymphocytes and Monocytes at Different Levels of Metabolism

In the above correlations the finding of a positive relationship between the neutrophile percentage and the height of the basal metabolic rate and a negative relationship between the lymphocyte percentage and the height of the metabolism was unexpected. Since hypopolynucleosis and relative lymphocytosis are common findings, one would expect a decrease in polymorphonuclears and an increase in lymphocytes as the metabolism increased. The explanation for this discrepancy is not clear.

It should be noted that the above discussion refers to the relative numbers of polymorphonuclears, lymphocytes and monocytes. When their absolute numbers are compared with the metabolic rates, all correlation is practically destroyed.

There is no significant correlation between the white blood cell count and its differential formula. On the other hand there is a highly signifi- 


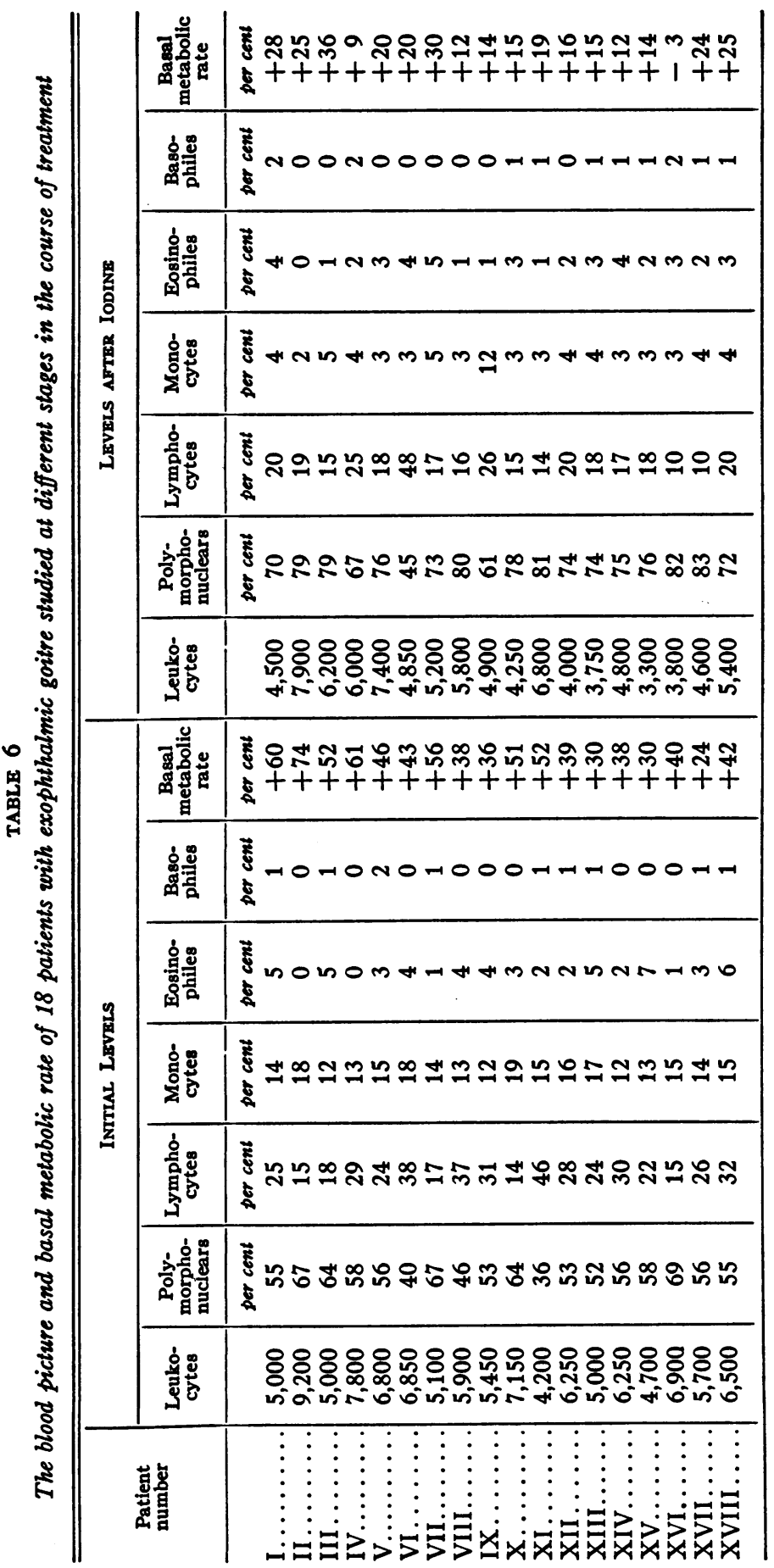




\begin{tabular}{|c|c|c|}
\hline \multirow{7}{*}{ 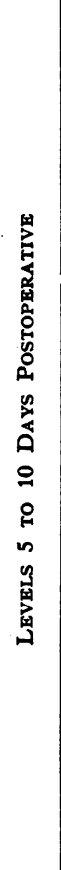 } & 要 & 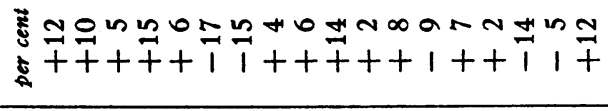 \\
\hline & 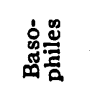 & $\begin{array}{l}\sum_{0}^{2} \\
\text { E }\end{array}$ \\
\hline & 蓠兽 & 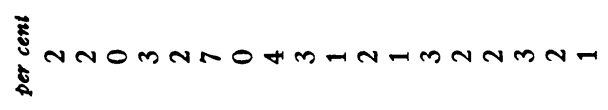 \\
\hline & 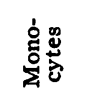 & 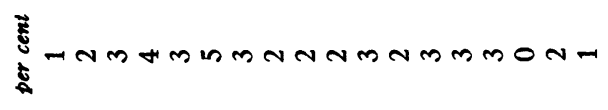 \\
\hline & 富忽 & 妾 \\
\hline & 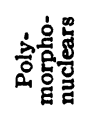 & 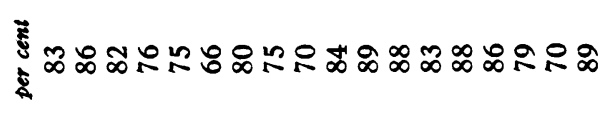 \\
\hline & क्ष̃ & 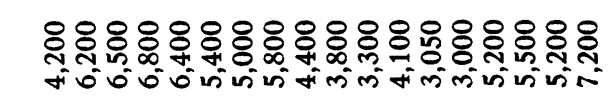 \\
\hline \multirow{6}{*}{ 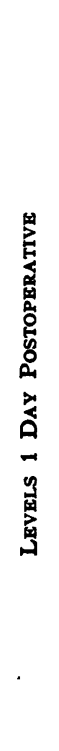 } & 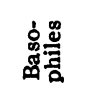 & 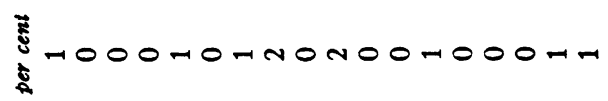 \\
\hline & 递离 & 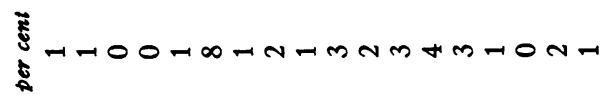 \\
\hline & 密 & 는 \\
\hline & 窇导 & 壳 \\
\hline & 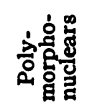 & 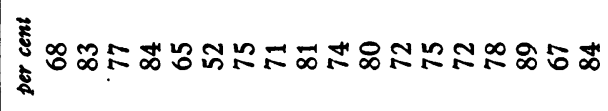 \\
\hline & 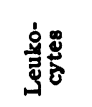 & 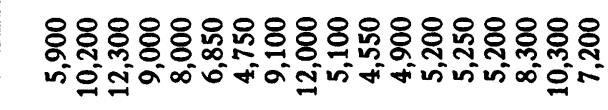 \\
\hline & & 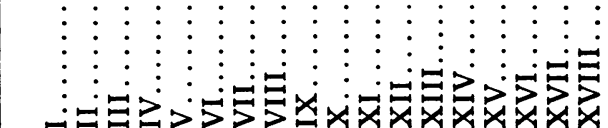 \\
\hline
\end{tabular}


cant inverse relationship between the polymorphonuclear and lymphocyte percentages and between the lymphocyte and monocyte percentages.

II

\section{CHANGES RESULTING FROM IODINE AND OPERATION}

Eighteen patients were studied under conditions of rest, iodinization and following operation and their data are presented in Table 6 . They include the levels of basal metabolism, white blood cell count, and differential formula of each patient. The postoperative period is divided into two in order to evaluate the effect of the postoperative febrile reaction and the final effect of operation.

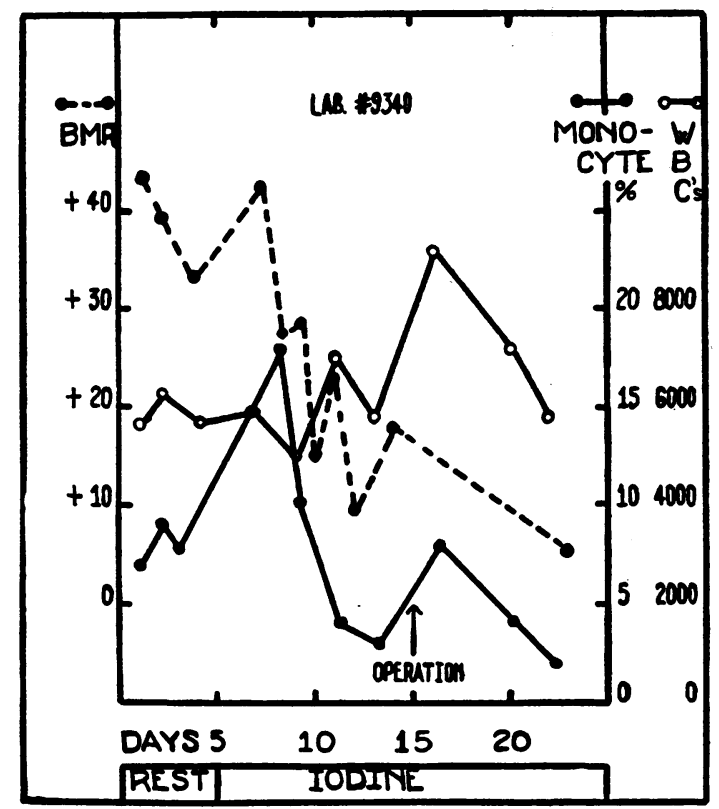

Fig. 3. Course of the Basal Metabolic Rate, White Blood Cell Count and Monocyte Percentage of a Patient with Exophthalmic Goitre

Figure 3 represents graphically the typical course of the basal metabolic rate, white blood cell count, and monocyte percentage of a patient undergoing the usual treatment of rest, iodine and operation. It demonstrates clearly that changes in monocyte percentage follow closely the changes in metabolism. The rise in metabolism seen in this case in the first few days after the beginning of iodine medication is not uncommon. There was a concomitant rise in monocyte percentage. The total white blood cell count changed little except for the moderate increase after operation. 


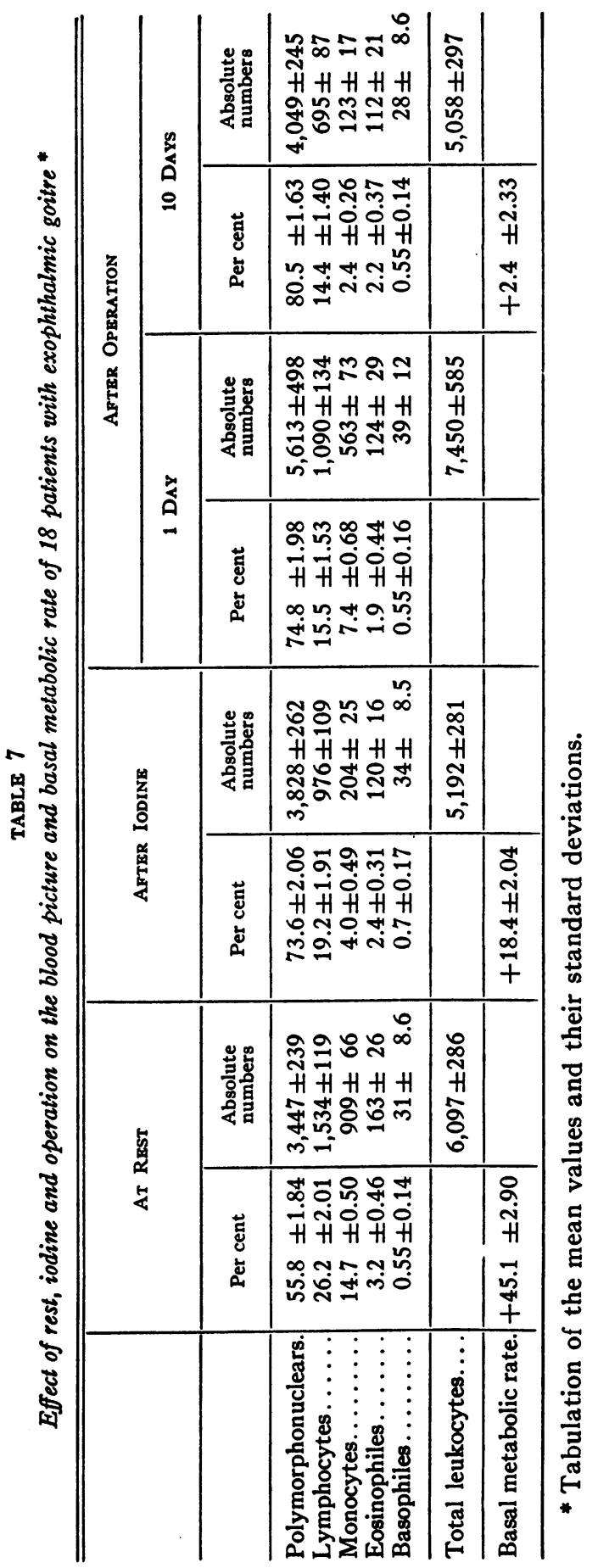


Table 7 summarizes the data presented in Table 6 and will serve as the basis for our subsequent discussion. As in the original table, the averages are arranged in columns to demonstrate the separate effects of rest, iodine, and operation on the blood picture and basal metabolism.

The resting levels for this group of patients are essentially similar to those obtained for the large group of untreated patients listed in Table 1, and require no further discussion. They serve as controls for the data on the same patients obtained after iodinization and operation. Rest, alone, as stated previously, had no appreciable effect on the blood picture even in those cases which showed considerable diminution in metabolic rate during the rest period.

Iodinization caused the following changes from the resting levels:

1. In 14 of the 18 cases there was a definite decrease in the total of white blood cells, varying from 100 to 3,100 cells; the remaining 4 cases showed an increase. The average decrease as shown in Table 8 amounted to $905 \pm 401$ cells or 15 per cent of the resting leukocyte count. This decrease is statistically significant.

2. There was a slight increase in absolute number of polymorphonuclear cells and a moderate increase in relative percentage. The latter increased in every case, whereas the former increased in 12 and decreased or was unchanged in 6 . The average increase in absolute number of cells was $381 \pm 355$ which is not significant; whereas the increase in percentage was $17.8 \pm 2.76$ per cent which is highly significant (see Table 8).

3. Both the small and large lymphocytes decreased. There was a slight increase in lymphocytes in 2 cases only. The average change in the lymphocytic series was $7.0 \pm 2.77$ per cent and $558 \pm 161$ cells for the relative and absolute numbers respectively.

4. The monocytes showed the most marked decrease, both in percentage and in absolute number. All but one of the patients showed a drop to the normal level of 2 to 5 per cent. A reduction in absolute number of monocytes occurred in every case. The average change was $10.7 \pm 0.70$ per cent and $705 \pm 71$ cells, both values being highly significant. This represents the most characteristic change in the blood picture in exophthalmic goitre under the influence of iodine.

5. There were variable changes in the percentage and absolute number of eosinophiles and basophiles, but none of these were definitely significant.

Some of the changes in the blood picture under the influence of iodine present interesting relationships to the simultaneous change in basal metabolic rate. The monocytes, both absolute and relative numbers, showed a reduction somewhat proportional to that of the metabolic rate. The changes in total leukocytes, percentage of polymorphonuclears, and 


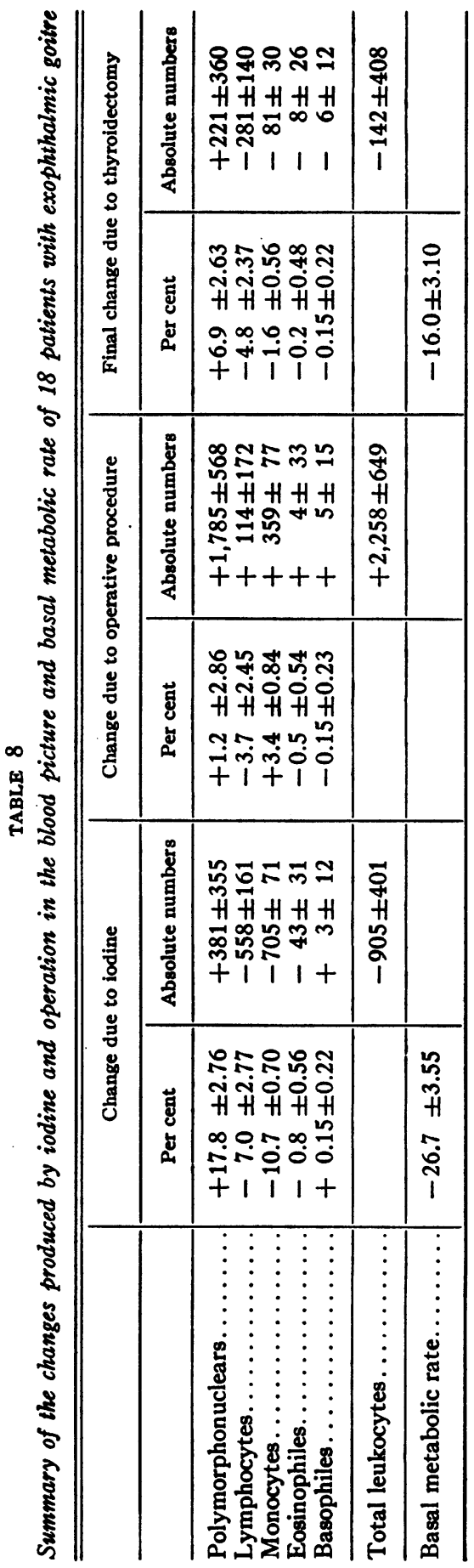


percentage and absolute number of lymphocytes showed no significant relationship to the changes in metabolism.

The immediate effect of operation on the blood picture is the resultant of several complex factors. There was a definite rise in total leukocyte count $(2,258 \pm 649$ cells $)$ which was mainly due to the rise in the number of polymorphonuclear cells $(1,785 \pm 568)$ and monocytes $(359 \pm 77)$. All the other types of cells changed slightly. The increase in monocytes was out of proportion to that of the other cell types. They were the only ones which showed a significant change in the relative number of cells, i.e. an increase of $3.4 \pm 0.84$ per cent.

The final state of the blood picture indicates that operation per se had relatively little effect upon it as compared to the effect of iodine. The polymorphonuclear cells increased slightly; the increase in percentage was statistically significant but the increase in absolute number was not. All the other cell elements decreased slightly, but only the lymphocytes and monocytes showed a significant change. Again the change in monocytes was proportionately larger than that of the other cells. The total leukocyte count decreased slightly (142 \pm 408 cells) but not significantly. Operation changes the blood picture of iodinized patients relatively little, whereas it decreases their metabolism considerably ( $16.0 \pm 3.10$ per cent). However, one cannot say that operation, alone, would fail to bring about the entire change in the blood picture recorded above.

\section{DISCUSSION}

The classification of white blood cells is much less arbitrary in the supravital technique than in the fixed smear. Differences in the techniques have been pointed out by Sabin, et al. in their quantitative studies of the daily rhythm of the white blood cells (15). Sources of error, which they thought were greatly reduced in the newer method, were the elimination of the "smudges" of fixed smear and the misclassification of the small monocytes, large lymphocytes and monolobed granular cells. It is not unusual to record an increase of 5 to 10 per cent in the percentage of monocytes by the supravital technique over that obtained by the fixed smear in cases of exophthalmic goitre.

Our experience with the various methods of blood study indicates that this misclassification of the monocytes in fixed smears may be the explanation of the apparent discrepancies found in the literature on the blood picture in exophthalmic goitre.

The effect of iodine on the blood picture in exophthalmic goitre is definite and almost constant. This stands in marked contrast to the findings reported by Jackson (12). His data, in addition to the fact that they were obtained by the fixed smear method, are subject to other sources of error. There is no indication that the monocytes were classified as a separate group. Moreover, conclusions are drawn from average 
values without due consideration for the variability of the results or the standard deviation. It seems to us that Jackson obtained the postiodine counts before the patients were fully iodinized because the reduction of 12 points (plus 46 to plus 34) in the basal metabolic rate of his group of cases is much smaller than the 30 or more point drop reported from other clinics, including our own. Consequently he attributes certain changes in the final blood picture to operation, which are probably due to iodine.

The elevated monocyte count in exophthalmic goitre and its depression by iodine in the course of the remission produced by this drug may be of fundamental importance in our understanding of the pathogenesis of the disease. If Aschoff's view that the monocyte of the circulating blood is part of the "reticulo-endothelial metabolic apparatus" (16) is correct, then our results suggest that the reticulo-endothelial system is activated in hyperthyroidism and that the remission produced by iodine is linked with a depression of this system. At the present time we are engaged in further experiments in an attempt to establish the validity of these suggestions.

\section{CONCLUSIONS}

1. The supravital technique offers a valuable aid in the study of the blood picture in exophthalmic goitre.

2. The discrepancies in the literature as to the blood picture in exophthalmic goitre are probably due to misclassification of the monocytes, a source of error which is reduced to a minimum by the use of the supravital technique.

3. The most marked and characteristic finding in the blood of patients with exophthalmic goitre is a relative and absolute monocytosis. Leukopenia and hypopolynucleosis are the rule. The percentage of lymphocytes is increased above normal in most cases, but relative lymphocytosis (of 30 per cent and over) occurred in only about a quarter of the cases. The absolute number of lymphocytes is normal.

4. The basal metabolic rate shows a direct correlation of probable significance with the percentage of monocytes and of polymorphonuclears respectively, and an inverse correlation of the same order with the percentage of lymphocytes. There is no relationship between the level of metabolism and the total leukocyte count.

5. The most characteristic effect on the blood picture of exophthalmic goitre from the administration of iodine is a reduction both in percentage and absolute number of monocytes. In addition, there is a moderate decrease in percentage and absolute number of lymphocytes, and a significant increase in the percentage but not in the absolute number of neutrophiles. The total number of leukocytes decreases in most cases.

6. The reduction in the number and percentage of monocytes tends to be proportional to the reduction in basal metabolic rate. The changes 
in the other cell elements and in the total leukocyte count do not show any such relationship to the basal metabolic rate.

7. The immediate effect of operation is to increase the total number of leukocytes, due chiefly to the increase in the number of polymorphonuclear cells and monocytes. Only the percentage of monocytes is significantly changed.

8. The final changes in the blood picture following operation are qualitatively the same as those produced by iodine but are much smaller. The total white blood cell count is reduced slightly but not significantly. The reduction in metabolism is proportionately greater than the change in the blood picture.

9. The possibility of depression of an activated reticulo-endothelial system in exophthalmic goitre by iodine is suggested by the data presented and is discussed briefly in the light of Aschoff's view of the origin of the monocyte.

We are indebted to Dr. James H. Means for supervision of this work and to Dr. Carl F. Doering, of the Department of Vital Statistics, School of Public Health, Harvard University, for guidance in the statistical treatment of the data.

\section{BIBLIOGRAPHY}

1. Ciuffini, P., Policlinico sez med., 1909, xvi, 289 and 364 . Ulteriore contributo alla ematologia del morbo di Flaiani-Basedow. I and II.

2. Caro, L., Berl. klin. Wchnschr., 1907, xliv, 519. Ein Fall von malignem Morbus Basedowii, kombiniert mit den Symptomen der Pseudoleukämie.

3. Caro, L., Berl. klin. Wchnschr., 1908, xlv, 1755. Blutbefunde bei Morbus Basedowii und bei Thyroidismus.

4. Kocher, Theodor, Arch. f. klin. Chir., 1908, lxxxvii, 131. Blutuntersuchungen bei Morbus Basedowii mit Beiträgen zur Frühdiagnose und Theorie der Krankheit.

5. Crotti, A., Thyroid and Thymus. Lea and Febiger, Philadelphia, 1922, 2nd ed. p. 389.

6. deQuervain, F., Goitre and Thyroid Disease. William Wood and Co., New York City, 1924, p. 80.

7. Müller, Charlotte, Med. Klin., 1910, vi, 1340. Ueber morphologische Blutveränderungen bei Struma.

8. Bauer, J. und Hinteregger, J., Ztschr. f. klin. Med., 1912, lxxvi, 115. Ueber das Blutbild bei endemischem Kropf und seine Beeinflussbarkeit durch Schilddrüsen- und Joddarreichung.

9. Lampé, A. E., Deutsche med. Wchnschr., 1912, xxxviii, 1127. Die Blutveränderungen bei Morbus Basedowii im Lichte neuerer Forschung.

10. Plummer, W. A., Minnesota, Med. 1919, ii, 330. The Blood Picture in Exophthalmic Goitre.

11. Menkin, V., Arch. Int. Med., 1928, xlii, 419. Relative Lymphocytosis in Hyperthyroidism.

12. Jackson, Arnold S., J. Am. Med. Assoc., 1931, xcvii, 1954. The Blood Picture in Six Hundred Cases of Goitre. 
13. Sabin, Florence R., Bull. Johns Hopkins Hosp., 1923, xxxiv, 277. Studies of Living Human Blood Cells.

14. Lerman, J., Am. J. Med. Sci., 1929, clxxviii, 54. A Comparison of Arsphenamin and Catarrhal Jaundice, with Special Reference to the Blood Picture.

15. Sabin, F. R., Cunningham, R. S., Doan, C. A. and Kindwall, J. A., Bull. Johns Hopkins Hosp., 1925, xxxvii, 14. The Normal Rhythm of the White Blood Cells.

16. Aschoff, L. and Kiyono, K., Folia haemat., 1913, xv, 383. Zur Frage der grossen Mononukleären. 